\title{
Martha Himmelfarb
}

\section{Merkavah Mysticism since Scholem: Rachel Elior's The Three Temples}

More than sixty years ago in Major Trends in Jewish Mysticism, Gershom Scholem delineated three stages of merkavah mysticism: the literature of the "anonymous conventicles of the old apocalyptics"; the speculation of the tannaim, the rabbis of the period from the destruction of the temple in 70 to the completion of the Mishnah around 200; and finally the hekhalot texts 1 . Of the three stages, it was the last stage to which Scholem gave most of his attention. He saw ascent to heaven as its central concern, and, in conformity with his view that mysticism was at the heart of Judaism in every age, he argued that its practitioners were deeply imbued with the values of rabbinic Judaism. But despite his claim that merkavah mysticism was the earliest phase of the ongoing tradition of Jewish mysticism, it is clear that Scholem saw it as of minor significance for understanding the culmination of that tradition, the kabbalistic systems of the Zohar and Isaac Luria. Indeed, Scholem concluded the chapter on merkavah mysticism in Major Trends by noting the distance between ancient merkavah speculation and the symbolic interpretation of the merkavah of later Jewish mystics ${ }^{2}$.

The decades since Scholem's pioneering work have seen important advances in the study of merkavah mysticism, including the publication of a synoptic edition of the major manuscripts of the hekhalot texts by Peter Schäfer ${ }^{3}$. The new scholarship develops Scholem's ideas further, but it also calls into question important aspects of his understanding of merkavah mysticism ${ }^{4}$. Some scholars have argued

1 Gerschom Scholem, Major Trends in Jewish Mysticism (New York 1961; first ed. 1941) 43.

2 Scholem, Major Trends 79. Merkavah mysticism receives little attention in: Moshe Idel, Kabbalah: New Perspectives (New Haven, London 1988), though he reads many rabbinic texts as reflecting a theurgic understanding of the meaning of the commandments similar to that of later kabbalistic texts (156-72, esp. 157). It plays a more important role in: Elliot $R$. Wolfson, Through a Speculum That Shines: Vision and Imagination in Medieval Mysticism (Princeton 1994). Wolfson understands merkavah mysticism as standing in continuity with later Jewish mysticism both because the hekhalot texts were redacted in the Middle Ages and because the medieval transformations of the vision of the merkavah are central to his project (9-10).

3 Peter Schäfer, Synopse zur Hekhalot-Literatur (Tübingen 1981).

4 To the best of my knowledge, there is no article or book chapter devoted to a critical discussion of scholarship on the hekhalot literature since Scholem. For recent listings of publications that supplement each other, see Rebecca Macy Lesses, Ritual Practices to Gain Power: Angels, Incantations, and Revelation in Early Jewish Mysticism (Harvard Theological 
that the adjuration of angels is as important to the hekhalot texts as ascent to heaven ${ }^{5}$ and that the relationship between the hekahlot texts and rabbinic Judaism is less direct and more complex than Scholem suggested 6 .

The view of the hekhalot texts as standing at the margins of rabbinic Judaism fits well with another important development in the study of merkavah mysticism, the virtual elimination of Scholem's second stage, the thought of the rabbis of the period of the Mishnah. The pseudepigraphic heroes of the hekhalot texts are drawn from among these rabbis, and Scholem assumed that some of what these texts report did in fact reflect the views of the tannaim, though he recognized the difficulties in this position ${ }^{7}$. But Scholem never undertook a systematic investigation of rabbinic discussions of the merkavah. When David J. Halperin did so in The Merkabab in Rabbinic Literature, he concluded, "The rabbinic sources ... taken by themselves, provide little reason to believe in the existence of the 'merkabab mysticism' envisioned by Scholem."

Scholem spent less time on his first stage of merkavah mysticism than on either of the other stages. Even the apocalypses he considered most important to the tradition of merkavah mysticism, the Apocalypse of Abrabam and 1 Enoch, are treated only briefly ${ }^{9}$. It is worth noting that in his only book devoted to merkavah mysticism, Jerwish Gnosticism, Merkavah Mysticism, and Talmudic Tradition ${ }^{10}$, Scholem turns to gnostic works and magical texts more than to the apocalypses to explicate particular aspects of merkavah mysticism. (It should be noted that Scho-

Studies 44, Harrisburg 1998) 3 n. 8; and James R. Davila, Descenders to the Chariot: The People behind the Hekhalot Literature (Supplements to the Journal for the Study of Judaism 70, Leiden, Boston, Köln 2001) 316-17.

5 Peter Schäfer, The Aim and Purpose of Early Jewish Mysticism, in: Hekhalot-Studien (TSAJ 19, Tübingen 1988) 277-95, and The Hidden and Manifest God: Some Major Themes in Early Jewish Mysticism, trans. Aubrey Pomerance (Albany 1992) esp. 142-46, 151-57; David J. Halperin, The Faces of the Chariot: Early Jewish Responses to Ezekiel's Vision (TSAJ 16, Tübingen 1988) esp. 376-87.

6 For a range of views on the nature of relationship, all at some distance from Scholem's: $P$. $S$. Alexander, The Historical Setting of the Hebrew Book of Enoch, in: JJS 28 (1977) 156-80; Halperin, Faces of the Chariot esp. 427-46; Schäfer, Aim and Purpose 289-95, and Hidden and Manifest God 157-61; Michael D. Swartz, Scholastic Magic: Ritual and Revelation in Early Jewish Mysticism (Princeton 1996) esp. 209-29.

7 Scholem, Major Trends 41-42.

8 (American Oriental Series 62, American Oriental Society, New Haven 1980) 184.

9 For the judgment about relative importance: Scholem, Major Trends 43. References to the Apocalypse of Abraham: Major Trends 68-69; Jewish Gnositicism 23-24, 30, 41-42, 129. Scholem does not differentiate among the five works included in 1 Enoch. The Book of the Watchers includes an account of Enoch's ascent and vision of the merkavah within the heavenly temple (1 Enoch 14); the Similitudes of Enoch includes several visions of God entroned in heaven and an account of the heavenly liturgy (1 Enoch 39-40, 46, 71). References to 1 Enoch: Major Trends 40, 67; Jewish Gnosticism 16, 30, 68, 129. Scholem mentions several other apocalypses as well, including 2 Enoch (Jewish Gnosticism 17, 130), 4 Ezra (Major Trends 40,54,63), and the Book of Revelation from the New Testament (Jewish Gnosticism $23,131)$.

10 (New York: Jewish Theological Seminary, 1960, rev. ed. 1965). The book is a brief collection of essays on the hekhalot literature and related rabbinic texts. 
lem drew only on gnostic literature known before the discovery of the Nag Hammadi library, which he was reluctant to use because the texts had not yet been thoroughly discussed ${ }^{11}$ ). These other bodies of literature illumine aspects of the hekhalot texts that the apocalypses cannot, such as the magical names that are so prominent in the hekhalot literature. But Scholem also points out that even the process of ascent that he takes as the defining characteristic of merkavah mysticism belongs to a larger Greco-Roman context ${ }^{12}$.

While Scholem paid rather little attention to the relationship between the apocalypses and the hekhalot literature, other scholars have done a great deal to illumine $\mathrm{it}^{13}$. Without the tannaim to serve as a conduit, however, the explanation for the parallels is far from obvious. The comparison of the apocalypses and the hekhalot literature has also contributed to the discussion about whether the apocalypses reflect visionary experience ${ }^{14}$, a discussion that has become more complicated as some students of hekhalot literature have called into question the once standard assumption that the hekhalot texts reflect actual practice ${ }^{15}$.

But Scholem can hardly be faulted for one of the most important gaps in his discussion of merkavah mysticism. I have already mentioned the Nag Hammadi find, which became known in 1946. The late 40's also saw the discovery of the Dead Sea Scrolls, a manuscript find of even greater relevance to ancient Jewish mysticism. The discovery came too late for Major Trends, and the painfully slow publication of the Scrolls was only in its beginning phases when Jewish Gnosticism appeared in 1960. The Scrolls, it turned out, did not contain any previously unknown accounts of ascent to heaven, but they did include several poetic texts that showed a connection in both content and style to the heavenly liturgy of the hekhalot texts and to their accounts of the heavenly halls. Scholem noted the potential significance for the study of Jewish mysticism of such poetic texts, mentioning both the Hodayot, the Thanksgiving Psalms, and the "Angelic Liturgy", as the Songs of the Sabbath Sacrifice was then known, in Jewish Gnosticism; in his additions to the

11 Scholem, Jewish Gnosticism 2.

12 Ascent to the merkavah is "a Jewish variation on one of the chief preoccupations of the second and third century gnostics and hemetics" (Scholem, Major Trends 49).

13 See, e.g.: Ithamar Gruenwald, Apocalyptic and Merkavah Mysticism (AGJU 14, Leiden, Köln 1980); Halperin, Faces of the Chariot 63-114; Martha Himmelfarb, Heavenly Asscent and the Relationship of the Apocalypses and the Hekbalot Literature, in: HUCA 59 (1988) 73-100; The Practice of Ascent in the Ancient Mediterranean World, in: Death, Ecstasy, and Other Worldly Journeys, ed. John J. Collins and Michael Fishbane (Albany 1995) 121-37.

14 For arguments in favor of seeing the apocalypses as records of visionary experience, e.g.: Daniel Merkur, The Visionary Practices of Jewish Apocalyptists, in: The Psychoanalytic Study of Society 14, ed. L. Bryce Boyer and Simon A. Grolnick (Hillsdale 1989); Michael E. Stone, Apocalyptic - Vision or Hallucination?, in: Milla wa-Milla 14 (1974) 47-56; Fourth Ezra (Hermeneia, Minneapolis 1990) esp. 121, 326-27, 429-31; On Reading an Apocalypse, in: Mysteries and Revelations: Apocalyptic Studies Since the Uppsala Colloquium, in: Journal for the Study of the Pseudepigrapha Supplement Series 9 (Sheffield 1991) 73-78. For arguments against this view: Himmelfarb, Ascent to Heaven in Jewish and Christian Apocalypses (New York 1993) 95-114.

15 Schäfer, Aim and Purpose 293-94; Halperin, Faces of the Chariot 441. 
second edition of Jewish Gnosticism, he comments that the publication of fragments of the Angelic Liturgy had borne out their significance for the hekhalot literature ${ }^{16}$. But Scholem never developed this observation further. This is not surprising. Scholem died in 1982; the first edition of all of the fragments of the Songs of the Sabbath Sacrifice was not published until 1985.

Scholem's intuition of the importance of the poetry of the Scrolls and of the Songs of the Sabbath Sacrifice in particular for the study of merkavah mysticism was certainly correct, and by now a great deal has been written on this subject ${ }^{17}$. There have also been some preliminary attempts to assess the relationship between the entire corpus of the Scrolls and the hekhalot literature ${ }^{18}$. But the most ambitious effort to date at taking account of the implications of the Scrolls for merkavah mysticism is the new book by Rachel Elior, The Three Temples: On the Emergence of Jewish Mysticism (2004; Hebrew original, 2002) ${ }^{19}$, which involves a thorough rethinking of the nature of early Jewish mysticism. With a few exceptions, the scholars who claim the Scrolls for early Jewish mysticism have not ventured beyond the Songs of the Sabbath Sacrifice and the Hodayot. While the Songs in particular plays a central role in her work, Elior's vision of the mystical system of the community at Qumran and its intellectual ancestors and descendants draws also on aspects of the Scrolls and related literature that are not usually discussed in this context, most importantly the calendar, but also the halakhah of the Scrolls. Elior's book is the culmination of a series of publications about the hekhalot literature going back into the $1980^{\prime} \mathrm{s}^{20}$, and her claims are both original and pro-

16 Scholem, Jewish Gnosticism 3-4, for the potential significance of Scrolls, though with some skepticism about the mystical character of the Hodayot, which he takes to be more the result of T. H. Gaster's translation than of the original. He alludes to the Scrolls also in chap. 3, "The Four Who Entered Paradise and Paul's Ascension to Paradise" (18; he knew Aramaic Levi from the Geniza material, not from the Scrolls), and in chap. 4, "The Merkabah Hymns and the Song of the Kine in a Talmudic Passage" (29), where he recognizes potential importance of a connection between the Scrolls and later Jewish mystical literature; the second edition adds a comment here about the content of the fragments (128).

17 See the review article of Elisabeth Hamacher, Die Sabbatopferlieder im Streit um Ursprung und Anfänge der jüdischen Mystik, in: JJS 27 (1996) 119-54. Ra'anan Abusch, Sevenfold Hymns in the Songs of the Sabbath Sacrifice and the Hekhalot Literature: Formalism, Hierarchy and the Limits of Human Participation, in: The Dead Sea Scrolls As Background to Postbiblical Judaism and Early Christianity: Papers from an International Conference at St. Andrews in 2001, ed. James R. Davila (STDJ 46, Leiden, Boston 2003) 220-47, appeared too late to be included in Hamacher's article.

18 See, e.g.: Yehudab (Lawrence) Schiffman, Sifrut ha-hekhalot v'kitvei qumran, in: Mehqere Yerushalaym Be-Mahshevet Yisra'el 6 (1987) 121-38; James R. Davila, The Dead Sea Scrolls and Merkavah Mysticism, in: The Dead Sea Scrolls in Their Historical Context, ed. Timothy H. Lim (Edinburgh 2000) 249-64; Michael D. Swartz, The Dead Sea Scrolls and Later Jewish Magic and Mysticism, in: DSD 8 (2001) 182-93.

19 Trans. David Louvish (Littman Library of Jewish Civilization, Oxford, Portland/OR 2004). The Hebrew original is entitled: Temple and Chariot, Priests and Angels, Sanctuary and Heavenly Sanctuaries in Early Jewish Mysticism (Jerusalem 2002).

20 The most recent develop themes treated in the book. See, e.g.: From Earthly Temple to Heavenly Shrines: Prayer and Sacred Song in the Hekhalot Literature and Its Relation to 
vocative. I should admit at the outset that I am skeptical of many of them, but their boldness and their comprehensive scope demand careful consideration.

Before going further, let me say a word about the use of the term "mysticism" in this paper. As some critics have pointed out, the discussion of the Scrolls and early Jewish mysticism has proceeded by and large without much attention to definition $^{21}$. Elior's book is no exception, though I believe that a definition is implicit in her work and could be extracted with proper care. But I am not going to undertake this task here because there are so many other aspects of Elior's work that I would like to consider. In what follows I use "mysticism" and "mystical" only when Elior has used them.

The title of the English version of Elior's book expresses her view that the literature under discussion took shape in three stages in relation to three absent temples $^{22}$. The first stage is the vision of the merkavah of Ezekiel, a priest in exile, on the eve of the destruction of the First Temple. The second stage is the literature of the priests who "seceded" from the Second Temple because they believed that the temple had been defiled by the practices of the establishment they opposed. The last stage is hekhalot literature, written in priestly circles after the destruction of the Second Temple 23 .

The fact that Elior describes three stages of early Jewish mysticism suggests a debt to the three stages Scholem outlined in Major Trends. But the stages Elior delineates are different from Scholem's, as is the center of her interests. Elior's first stage, the vision of the prophet Ezekiel, does not appear in Scholem's schema. For Elior, it serves to establish the conditions of authorship she claims for all of the literature under discussion: the authors are priests deprived of their temples, or at least people influenced by such priests. Elior's second stage corresponds roughly to Scholem's first, apocalyptic literature. But while Scholem passes quickly over this stage, it is the focus of Elior's project. For Elior the Scrolls play a crucial role, as they could not for Scholem. Scholem's second stage is the thought of the tannaim. Elior omits this stage altogether. I noted above that scholarship after Scholem has put this stage into question. For Elior, as we shall see, the thought of the rabbis stands in opposition to the mystical system created by priests. Scholem's third stage, hekhalot literature, is the focus of his work. This literature constitutes Elior's third stage as well, and she also devotes considerable attention to it.

Temple Traditions, in: JSQ 4 (1997) 217-67, and: The Merkavab Tradition and the Emergence of Jewish Mysticism: From Temple to Merkavah, from Hekhal to Hekbalot, from Priestly Opposition to Gazing upon the Merkavah, in: Sino-Judaica: Jews and Chinese in Historical Dialogue, ed. Aharon Oppenheimer (Tel Aviv 1999) 101-58. The latter offers a condensed version of much of the book.

21 Elliot $R$. Wolfson, Mysticism and the Poetic-Liturgical Compositions from Qumran: A Response to Bilhah Nitzan, in: JQR 85 (1994) 185-202; Swartz, Dead Sea Scrolls 182-90.

22 The explanation of the three temples appears in: Merkavab Tradition 103-04; the introduction to Three Temples (1-24) offers a similar historical overview, but as far as I can see, the book never offers an explicit explanation for its title.

23 Elior, Three Temples 12-14, 232-44. 
The texts Elior associates with the central second stage are quite diverse. They include clearly sectarian works from the Scrolls, such as the Damascus Document, the Rule of the Community, and 4QMMT; texts from among the Scrolls that stand in a more indirect relationship to the sect, such as the Songs of the Sabbath Sacrifice and the Temple Scroll; and texts such as Aramaic Levi, the Book of the Watchers, the Astronomical Book, and the Book of Jubilees, which pre-date the sect, but appear among the Scrolls. Elior is certainly justified in claiming that all of the texts just mentioned were of interest to the sectarians, even if many were not composed by them. But she is even more inclusive - in my view, unjustifiably soin defining the corpus relevant to her protagonists. 2 Enoch, for example, clearly draws on earlier Enochic literature, but was composed not in Hebrew or Aramaic in Palestine, but in Greek, perhaps in Alexandria, at an uncertain date. Her use of the Wisdom of ben Sira as evidence for the point of view of the secessionist priests is even more surprising ${ }^{24}$. Ben Sira is usually understood as writing on behalf of the very priestly establishment from which Elior's protagonists seceded, and some recent scholarship has suggested that he was engaged in a polemic against the school represented by the Book of the Watchers ${ }^{25}$. Furthermore, because Elior takes the works that she associates with the secessionist priesthood to attest a common, well-defined worldview, she more or less ignores the ways they differ among themselves, though in my view these differences are sometimes as important as the similarities. This is a criticism to which I shall return several times in the course of my discussion.

The mystical system Elior discerns in the texts she treats is intimately related to the temple, its rituals, and its calendar. I begin with Elior's own summary:

"Basic to the sacred service [of the temple] was the perception of heaven and earth as a unity, so that one could postulate the existence of a mutual relationship between the cosmic cyclicity of the eternal, incorporeal, divine realm and the ritual cyclicity established in the material, terrestrial realm by the sacred service...

The precise ceremonial, symbolic language of the cyclic ritual represented the cosmic cycle in terms of number and time, through the cycle of sabbaths and festivals and in the set times for the offering of sacrifices...

The synchronization thus established between the set times of God, grouped in sevens; the set times of nature, grouped in fours; and the set times of the sacred service, which wove them together, created the tradition of the Merkavah, the holy Chariot Throne, as a bridge between the supernal and its sanctified manifestations in the human world, as deciphered in ritual, cycle, number, and song. All these set times were dependent on a sacred calendar, which regulated the course of

24 Elior, Three Temples 97, 185, 199.

25 Benjamin Wright III, 'Fear the Lord and Honor the Priest': Ben Sira as Defender of the Jerusalem Priesthood, in: The Book of Ben Sira in Modern Research: Proceedings of the First International Ben Sira Conference 28-31 July 1996, Sosterberg, Netherlands (Berlin, New York 1997) 189-222; Randall A. Argall, 1 Enoch and Sirach: A Comparative and Conceptual Analysis of the Themes of Revelation, Creation, and Judgment (Early Judaism and Its Literature 8, Atlanta 1995). 
time - the creator of life; on the divine structure of sacred space - the source of life; and on the sanctity and purity of the priests as they performed the sacred service the guarantee that life would continue. The synchronization of the sacred service was established and maintained by virtue of a sacred authority of supernatural origin, with a variety of manifestations: the word and commandments of God, "wondrous secrets" or divine revelation and angelic testimony, heavenly tablets, books dictated from on high, laws observed by angels and priests, divine election, purity and sanctification, and sacred scriptures." 26

The calendar to which the passage refers is the 364-day solar calendar. Elior accepts the broad outlines of Annie Jaubert's theory that this calendar was the temple's original calendar ${ }^{27}$. Thus she understands the acceptance of the lunar calendar by the Hasmonean high priests after the success of the Maccabean revolt as an important cause of the secession of the Zadokite priests who are her subject. Here I must sound a note of caution. The position Elior embraces is shared by many other scholars; I am inclined to accept it myself. But the evidence is hardly as clear as she suggests, and many scholars understand the situation quite differently. Indeed, if one thing about the calendar at Qumran can be said to be clear, it is that more than one type of calendar had some authority there ${ }^{28}$.

Even if Elior is correct that the 364-day calendar is the ancient calendar of the temple, she does not do justice to the complexity of the evidence for that calendar, which includes a variety of quite technical texts from among the Scrolls, as well as the Astronomical Book (1 Enoch 72-82) and the Aramaic fragments of the longer work on which it is based, the Temple Scroll, and the Book of Jubilees. Rather, she assumes that all of these texts embrace all of the festivals mentioned in any of them and also reflect a common ideology. Thus Elior's account of the agricultural festivals of the calendar draws primarily on the Temple Scroll, while her understanding of the ideology of the calendars relies largely on Jubilees ${ }^{29}$. The choice of $J u b i$ lees is certainly understandable since it is the only one of the texts to provide much indication of the meaning of the calendrical arrangements. Yet Elior's assumption that Jubilees speaks for all proponents of the 364-day calendar is problematic, as we shall see.

The 364-day calendar is based on the number seven, so crucial to the biblical ordering of time. A year according to this calendar contains exactly fifty-two weeks, divided into twelve months. The months are divided into four seasons of three months or thirteen weeks each. Most months consist of thirty days, but there is an

26 Elior, Three Temples 3.

27 Annie Jaubert, Le calendrier des Jubilés et de la secte de Qumrân: Ses origines bibliques, in: VT 3 (1953) 250-64; Le calendrier des Jubilés et les jours liturgiques de la semaine, in: VT 7 (1957) 35-61.

28 For evidence for use of a lunar calendar at Qumran alongside the 364-day calendar: J. $M$. Baumgarten, 4Q503 (Daily Prayers) and the Lunar Calendar, in: RevQ 12 (1986) 399-407. For a more general perspective on the multiplicity of calendars at Qumran: Sasha Stern, Qumran Calendars: Theory and Practice, in: Lim (ed.), Dead Sea Scrolls 179-86.

29 Elior, Three Temples 52-53. 
additional day at the beginning of each of the first months of a season, that is, the first, fourth, seventh, and tenth months. The mathematical regularity and harmony of the 364-day calendar avoids the problems posed by the lunar calendar, which, at least according to the rabbis' view, required observation of the new moon to determine the start of the new month. In this highly symmetrical calendar, no festival conflicts with the sabbath, and each festival falls on the same day of the week year after year ${ }^{30}$. Elior also notes the texts from Qumran concerned with the relationship between this calendar and the twenty-four priestly courses described in the biblical Book of Chronicles: the twenty-four priestly courses followed in turn through the years so that at the end of six years, each course would have served thirteen times. She does not seem concerned that the ad hoc quality of this particular mathematical relationship detracts from the symmetry of the correspondence, though she does note that the War Scroll offered a more elegant solution, a system of twenty-six priestly courses ${ }^{31}$.

The calendar also attempts to bring its symmetrical ordering of time by the artificial unit of the week into harmony with nature, though its treatment of the agricultural year is also symmetrical and stylized. The agricultural year extends from the middle of the first month to the middle of the seventh month and is marked by seven-day festivals at each end, Passover and the Feast of Booths. Further, starting with the waving of the barley sheaves on the Sunday of Passover, that is, the day after the sabbath (Lev. 23:11,15), every seventh Sunday is the occasion for a firstfruits festival: the first fruits of the barley, as dictated in the Torah (Lev. 23:15-21), in the eleventh week; the first wine in the eighteenth week; and the festival of the first oil in the twenty-fifth week. The day after the oil festival was the festival of the wood offering; together they formed a seven-day festival ${ }^{32}$.

The 364-day calendar is no human invention. It is engraved on the heavenly tablets, and it was revealed to humanity by Enoch, the seventh patriarch, who ascended to heaven to learn the divine secrets. Before it was known on earth, its festivals were already observed in heaven by God and the angels ${ }^{33}$. Just as the solar calendar is associated with Enoch's ascent, the lunar calendar is associated with its negative counterpart, the myth of the descent of the Watchers, the angels who came down to earth, took women as sexual partners, and led humanity astray, revealing dangerous and false knowledge, including "the course of the moon" 34 . Elior points out that the Book of the Watchers' account of the sins committed by the Watchers underlines the role of the senses. While the lunar calendar requires human observation, the beauty of the 364-day calendar is that it is mathematically determined, leaving no role for the senses ${ }^{35}$.

30 Elior, Three Temples 45-58.

31 Elior, Three Temples 42-44.

32 Elior, Three Temples 52-53, based on the Temple Scroll.

33 Elior, Three Temples 83.

34 Elior, Three Temples 115.

35 Elior, Three Temples 116. 
Elior contrasts the calendar of the secessionist priests to that of the rabbis and claims that the differences reflect profound differences in worldview:

"On the one hand was a deterministic perception of time, of heavenly origin, bound up with the cyclic laws of nature as reflected in a fixed solar calendar whose festivals fell not only on fixed days of the month but also on fixed days of the week, a calendar maintained unchanged by angels and priests who attested to its divine origin... On the other was a perception of time dependent on variable, human decisions, governed by observations made by ordinary mortals, as reflected in a changeable, lunar calendar, maintained by leaders who derived their authority from the people as a whole, by a court which heard testimony from any witness, took terrestrial interests and the good of the Community into consideration, and invoked, as a crucial principle, 'It is not in the heavens'." 36

The juxtaposition of disaffected priests of the Second Temple period with the rabbis of the period after the destruction opens Elior to charges of anachronism. Though she does not pause to justify the juxtaposition, I believe that Elior is in fact following the considerable body of scholarship that understands the halakhic texts from Qumran as evidence for a priestly halakhah that stood in opposition to the antecedents of rabbinic halakhah ${ }^{37}$. I have reservations about this picture, but in recent years it has been widely held, and Elior should not be faulted for adopting it, though she should certainly have explained what she was doing.

The discussion of the calendar illustrates both the strengths and the weaknesses of Elior's work. The difference in attitudes toward time reflected in the 364-day calendar on the one hand, and the luni-solar calendar of the rabbis on the other is indeed profound, but Elior fails to recognize how much her understanding of the significance of the 364-day calendar is indebted to Jubilees. Consider, for example, the Astronomical Book, another work found at Quman that adheres to a 364-day calendar. The Astronomical Book is much less ill-disposed toward moon than it should be according to Elior. While it calls the moon the "smaller luminary" (1 Enoch 73:1), it also makes it one of "the two great luminaries" (1 Enoch 78:3). The Ethiopic version of the Astronomical Book contains considerable detail about the phases of the moon and the relationship between the travels of the moon and of the sun (1 Enoch 73-74, 78-79), and the Aramaic fragments offer an even more extensive treatment of the moon without any negative comment. Thus, though the moon is clearly subordinate to the sun, the considerable attention to the moon, its course, and its phases, in the Astronomical Book would be intolerable to Jubilees,

36 Elior, Three Temples 109-10.

37 See, e.g.: J. M. Baumgarten, The Pharisaic-Sadducean Controversies about Purity and the Qumran Texts, in: JJS 31 (1980) 157-70; Ya'aqov Sussman, Heqer toldot ha-halakhah umegillot midbar-yehudah: hirhurim talmudiim rishonim l'or megillah miqzat ma'aseii ha-torah, in: Tarbiz 59(1989-90) 11-76 (English translation without extensive annotation: Appendix 1: The History of Halakha and the Dead Sea Scrolls: Preliminary Talmudic Observations on MIQSAT MA'AŚE HA-TORAH [4QMMT], in: Qumran Cave 4.V: Miqsat Ma'aśe haTorah, ed. Elisha Qimron and Jobn Strugnell [DJD 10; Oxford 1994] 179-200); Lawerence H. Schiffman, Pharisaic and Sadducean Halakhah in Light of the Dead Sea Scrolls: The Case of Tevul Yom, in: DSD 1 (1994) 285-99. 
which truly detests the moon. It is hard to reconcile the elaborate attempt at harmonizing the courses of the sun and moon in the Astronomical Book ${ }^{38}$ with the powerful polemic against any use of the moon for purposes of dating in Jubilees. The only polemic in the Astronomical Book, far milder than that of Jubilees, is directed not against the lunar calendar, but against a year of 360 days. The heightened rhetoric of Jubilees, which was written after the Maccabean Revolt ${ }^{39}$, presumably reflects anger over the abandonment of the traditional calendar by the temple establishment. If Elior is correct in her understanding of the history of the temple calendar, the Astronomical Book, which may be as early as the fourth century $\mathrm{BCE}$ and undoubtedly predates the Hasmonean assumption of high priesthood ${ }^{40}$, has no such cause for anger; its calendar was in force in the temple when it was written. In other words, the contrast Elior draws between secessionist priests and rabbis is really a contrast between the author of Jubilees and the rabbis. Further, if the 364-day calendar was the calendar of the temple in pre-Hasmonean times, it was not the sole property of the secessionist priests, and certainly not their creation. Thus to link it to the worldview of those priests in contrast to the temple establishment - the object of the polemic of Jubilees and of the Scrolls - is problematic.

Nor does Elior's linking of the lunar calendar to the teaching of the Watchers stand up to scrutiny. The primary evidence Elior cites for this link comes from the Book of the Watchers, which twice mentions an angel named Sahariel, who taught the signs, or in Elior's translation, the course of the moon (1 Enoch 6:7, 8:3; his teaching is noted only in the second passage $)^{41}$. Yet Elior neglects to note that the angel preceding Sahariel in both lists is Shamsiel, who taught the signs of the sun (1 Enoch 6:7, 8:3; his teaching is noted only in the second passage). In other words, according to the Book of the Watchers there is no more connection between the teachings of the fallen Watchers and the lunar calendar than there is between their teachings and the solar calendar. It is also worth remembering that the calendar does not appear to be high on the list of concerns of the Book of the Watchers; while it alludes to the Astronomical Book at the conclusion of its journey to the ends of the earth (1 Enoch 33-36), it never makes explicit reference to the calendar.

38 Otto Neugebauer, Appendix A: The 'Astronomical' Chapters of the Ethiopic Book of Enoch (72-82), in: Matthew Black in consultation with James C. VanderKam, The Book of Enoch or I Enoch: A New English Translation (SVTP 7, Leiden 1985) 400-01, thinks that the most explicit effort to coordinate solar and lunar years in 74:10-17 are a later addition by a scribe.

39 This is the current consensus on the date of Jubilees; for arguments for a post-Maccabean date: James C. VanderKam, The Origins and Purposes of the Book of Jubilees, in: Studies in the Book of Jubilees, ed. Matthias Albani, Jörg Frey, and Armin Lange (TSAJ 65, Tübingen 1997) 12-16, 19-21.

40 On the date of the Astronomical Book, see, e.g.: George W. E. Nickelsburg, 1 Enoch 1: A Commentary on the Book of 1 Enoch, Chapters 1-36; 81-108 (Hermeneia, Minneapolis 2001) 7-8.

41 Elior, Three Temples 119-20; for the translation "signs" for both moon and sun, Nickelsburg, 1 Enoch 1. 
Elior also cites Jubilees' worry about the corrupting effect of observing the moon in her discussion of the myth of origins of the lunar calendar $(J u b 6: 36-37)^{42}$. But Jubilees' telling of the story of the Watchers emphasizes their sexual $\sin (J u b 4: 22)$; though it claims that God sent them to earth to teach $(J u b 4: 15)$, it never accuses them of the false or dangerous teachings of the Book of the Watchers and certainly does not connect them to the lunar calendar. Thus, I do not believe that the attribution of the lunar calendar to the Watchers can be found in the ancient texts; rather, it is Elior who provides this satisfyingly symmetrical counterpart to Enoch's association with the 364-day calendar.

Another crucial aspect of the worldview of her protagonists according to Elior is the association of priests with angels. She rightly claims that this association is central to many of the works she considers, such as the Book of the Watchers and Aramaic Levi. The Songs of the Sabbath Sacrifice is of particular interest to Elior in this context. She sees in it an implicit correspondence between the angelic priests of the heavenly sanctuary that are its subject and earthly priests ${ }^{43}$; indeed, human recitation of this account of the heavenly liturgy enacts the correlation of heaven and earth ${ }^{44}$. Elior also suggests that the Qumran community's self-designation, yahad, means more than "community" in a neutral sense, as it is usually translated, for example, in the title of $1 \mathrm{QS}$, the Rule of the Community. Rather, it refers to the community's status as earthly counterpart to the angelic host, the "togetherness" of sectarians and angels ${ }^{45}$. Unfortunately, she never provides the arguments, philological or contextual, for this intriguing claim ${ }^{46}$. She also notes the relationship between the stringent purity rules of the community and its sense of the presence of the angels, explicit in some texts, implicit in others ${ }^{47}$, and, as we have seen, she suggests that the community understood its 364-day calendar as the calendar of the angels as well. But her claims for the connection between priests and angels are even stronger:

"Angels are not only the major subject of belief in the priestly literature, but also, as it were, an 'invention' or 'formation' of the priestly literature; they are the allies of the sons of Aaron... who minister in the holy precincts. This fact is the basis for their presence or absence in various bodies of literature, whether those that aim to confirm the priestly myth or those that wish to reject or weaken it." 48

Elior is undoubtedly correct that many texts of the Second Temple period assume a correspondence between the temple on earth and heaven understood as a temple and thus a correspondence between priests and angels. Yet as with her dis-

42 Elior, Three Temples 115-16.

43 Elior, Three Temples 186-90.

44 The Songs of the Sabbath Sacrifice figures prominently in the chapter of Three Temples entitled, "Priests and Angels" (165-200).

45 Elior, Three Temples 171 and elsewhere.

46 Perhaps Elior was influenced by the musaf qedushab of nusab sefard: "A crown, Lord our God, do the angels give you, the multitude on high, with your people Israel, the assemblies below. Together they all triply proclaim your holiness ..."

47 Elior, Three Temples 181-2.

48 Elior, Three Temples 182. 
cussion of calendar, Elior shows little concern for the details of individual texts and differences among them, and her harmonization of her sources obscures important differences. Thus, for example, while all of the halakhic literature found among the Scrolls intensifies the purity laws relative to Leviticus, two of the most important legal texts, the Temple Scroll and the legal portions of 4QD, do so without reference to angels. Or, to offer another example, at least one text central to Elior's picture of the secessionist priesthood, the Book of Jubilees, claims not priests alone, but all Israel, as the earthly counterpart of the angels. I believe that this claim should be understood as a response to sectarian definitions of Israel that excluded most Jews from membership ${ }^{49}$. In any case, the texts Elior considers were hardly of one mind on this topic.

Finally, Elior's claim that angels are uniquely the interest of adherents of the priestly myth is simply wrong. Angels also play a central role in works that surely do not belong to the corpus of the secessionist priesthood: the Book of Daniel, for example, the Apocalypse of Abraham, the Book of Revelation in the New Testament, 4 Ezra, or 2 Baruch. Elior might reasonably respond that although 4 Ezra and 2 Baruch provide their heroes with angelic interlocutors, they do not suggest a heavenly sanctuary full of angelic priests. But this objection does not apply to the other works just noted. Scholem called the Apocalypse of Abraham with its elaborate picture of the merkavah and its angelic song, "a text that more closely resembles a Merkabah text than any other in Jewish apocalyptic literature" 50 ; Daniel combines imagery of the royal court with that of the temple for its picture of the heavenly throne room; and the Book of Revelation, which also stands very close to the merkavah tradition, gives the heavenly cult and its angelic priests an important place ${ }^{51}$. Indeed, the notion of heaven as a temple with angels as its priests is so widespread in apocalypses that its presence can hardly be taken as indicating a particular point of view - and I suspect that the same is true of its absence in works such as the Book of Dreams (1 Enoch 83-90) or the Epistle of Enoch (1 Enoch 92105), which lack a description of heaven as temple, but explicitly claim connection to the traditions about Enoch.

While I have criticized aspects of Elior's claims about calendar and the correlation of priests and angels, there can be no doubt that Elior is correct to see these themes as important to the literature she is discussing. I do not believe the same can be said for the myth of sacred marriage that Elior finds in early Jewish mysticism.

Early in the book, Elior attempts to link the calendar of the secessionist priesthood to human fertility:

"The concepts of season, cycle, sanctity, four/quarter, seven/week/oath (all three derive from the same root in Hebrew $s b-v-a$ ), purity and benediction, com-

49 I argue for this reading in the chapter on Jubilees in my book: A Kingdom of Priests: Ancestry and Merit in Ancient Judaism (Philadelphia 2006).

50 Scholem, Jewish Gnosticism 23.

51 On Revelation and the merkavah tradition, see, e g.: Gruenwald, Apocalyptic 62-69, and Halperin, Faces of the Chariot 87-96. 
munity and communion, all have double meanings, referring to sacred time and place alike and through them to the divine Covenant, to the cycle of seven festivals, to holiness and benediction. On the human plane, the same concepts are also associated with betrothal and union for purposes of fertility and reproduction, which involve cycles of ovulation counted in four-week periods, the seven-day term of the period of purification, self-sanctification, covenant and oath, the seven benedictions of betrothal, the husband's conjugal duties and the laws governing conjugal union." 52

The length of the cycle of ovulation, of course, is not necessarily four weeks, but it is not implausible that proponents of a calendar that set the length of a month without regard to the variability of the moon's course might have preferred an idealized timetable for ovulation. Yet, to the reader's astonishment, Elior explicitly invokes the variability of the moon in relation to human fertility with positive implications:

"The rhythm of feminine fertility is associated with the cycle of the moon with its phases; indeed, the Hebrew word for the waxing of the moon, ibur, also means 'conception'; while the Hebrew word for the appearance of the new moon, molad, is of the same root $(w-l-d)$ as the word ledab, 'birth', and its cognates; similarly the words that refer to a woman's monthly cycle may also be applied to the lunar phases. Both cycles are associated with the passage of four weeks. A menstruating woman is forbidden to her husband until seven 'clean' days (i.e. days on which no blood whatsoever has been seen) have elapsed, and only then - when the probability of conception is highest - may cohabitation occur. The ritual calendar was concerned with the Temple and the Holy of Holies; with sabbaths, festivals, and sacrifices; with purity and impurity; with sabbatical years and jubilees. The personal calendar was associated with sanctification, betrothal, isolation (when a woman is menstruating or otherwise 'unclean'), purification and cohabitation. Both calendars... were marked off in sevens; both guaranteed continued fertility, the eternal continuity of life as dependent on a sevenfold rhythm; and both involved counting and number, oath and covenant, testimony and set times, holiness and sanctification, unification and separation, the eternity of Creation." 53

Elior does nothing to explain how those who, in her view, understood the lunar calendar as the teaching of the fallen Watchers could possibly have held this set of positive associations for the moon; indeed she shows no awareness at all that explanation is required. There are other problems too in the passages just quoted. The seven-day period of purification reflects not the halakhah of the secessionist priests, but of the rabbis, who mandate seven "clean" days following menstruation before the resumption of sexual relations. The Temple Scroll and 4QD intensify the purity laws in a number of ways, but do not go beyond the Torah's rule of a seven-day period of impurity starting with the beginning of menstruation. Nor,

52 Elior, Three Temples 40.

53 Elior, Three Temples 55. 
as far as I know, is there any evidence that the seven benedictions of the wedding ceremony date back to the Second Temple period 54 .

But the sexual relations that figure in Elior's understanding of her mystical system are not only relations between human beings, but also the relations between God and the people of Israel. Elior begins by noting the association of Ezekiel's vision of the merkavah with Shavu'ot, the festival whose very name (from the root seven/week/oath) is significant. Shavu'ot, which falls seven weeks after Passover, comes to be understood as the moment of the marriage of the people of Israel and the Lord. Elior refers to "traditions, both early and late" on this point, but she does not mention any that predate rabbinic times, and as far as I know there are none $e^{55}$.

The central text for Elior's discussion of the merkavah as connected to a myth of sacred marriage is a passage from the Bavli about the cherubim in the Holy of Holies, that is, the earthly counterpart to the merkavah:

"Whenever Israel came on pilgrimage on the festivals [to the Temple in Jerusalem], the curtain would be removed for them and the cherubim were shown to them, whose bodies were intertwined with one another, and they would be thus addressed: Look! You are beloved before God as the love between man and woman (B. Yoma 54a)." 56

"The description in the Talmud... suggests a cultic mystical representation of myths of bieros gamos, the sacred union or heavenly matrimony, probably in the context of the pilgrimage on Shavuot...", Elior writes ${ }^{57}$. The passage, however, associates the exhibition of the cherubim with the pilgrimage festivals in general rather than Shavu'ot in particular. Further, the erotic interpretation of the temple in the Bavli is not restricted to the cherubim with their connection to the merkavah, for the passage Elior quotes is part of a discussion of the equipment of the temple that includes an erotic interpretation of the poles of the sanctuary as well. Elior finds support for her claim that a myth of sacred marriage is part of early Jewish mysticism in material from Sefer Yetzirah, various rabbinic texts, especially those related to the Song of Songs, and, finally, the Zohar ${ }^{58}$, but she does not note the recent scholarship that has suggested that the enthronement of the divine glory in Hekbalot Rabbati is a sort of sacred marriage, with the throne as the female party ${ }^{59}$.

54 The discussion in Michael L. Satlow, Jewish Marriage in Antiquity (Princeton, Oxford 2001 ), assumes that the blessings derive from the rabbinic period $(63-67,178-79)$.

55 Elior, Three Temples 157-58, quotation 157.

56 I take the translation from Elior, Three Temples 158; the words in brackets are part of that translation. The original language of the passage is Hebrew.

57 Elior, Three Temples 158.

58 Elior, Three Temples 157-64.

59 Wolfson, Through a Speculum 98-105. Elior's lack of attention is surprising, especially since she discusses one of the passages Wolfson points to as evidence of Throne-Glory relations (Three Temples 251-52). For Elior the passage is evidence of ongoing interest in the temple's equipment in the hekhalot literature. 
Elior goes on to suggest that the story of the Watchers represents a negative counterpart to the myth of sacred marriage:

"The cherubim, sacred beings associated with creation and life, sanctity and holy matrimony, with appropriate covering and uncovering of what is properly hidden, with sacred union and connubiality, with fertility and procreation, with holiness, purity, and sevenfold enumeration, are the antithesis of the Watchers, who embody forbidden, unrestrained, monstrous sex, impurity devoid of enumeration, profanation of everything that is sacred, violation of boundaries and prohibition, incest, idolatry and bloodshed, death and destruction."60

If the story of the Watchers is the negative counterpart to the myth, the myth itself must be as early as the story of the Watchers, that is, it must go back to the Second Temple period. Elior appears to recognize the difficulties in claiming that the myth of sacred marriage, found only in later texts, dates so far back, and she begins her conclusion cautiously: "These diverse observations may point to ancient priestly-mystical traditions ..."61. Of course, she has already suggested that the Bavli's report about the unveiling of the cherubim may be "an echo of an ancient tradition of the First Temple", since there was no cherubim-throne in the Second Temple 62 . Nor is dating the only difficulty with Elior's reading of the myth of the Watchers. While she is surely correct that the Watchers' behavior is a negative model of sexual relations, many students of the story have understood it to reflect disapproval not of sexual immorality in general, but rather of marriages between priests and women inappropriate for them that were current at the time the Book of the Watchers was composed 63 .

It is surely not irrelevant to Elior's claims that she is an expert in later Jewish mysticism where the symbolism of sacred marriage plays a central role 64 . I have already noted Scholem's acknowledgment of the differences between merkavah mysticism and later Jewish mysticism. The presence of a myth of sacred marriage in merkavah mysticism would strengthen the connection with later Jewish mysticism. Yet as far as I know the evidence for such a myth in the hekhalot literature is

60 Elior, Three Temples 163.

61 Elior, Three Temples 163; italics mine.

62 Elior, Three Temples 158.

63 George W. E. Nickelsburg, Enoch, Levi, and Peter: Recipients of Revelation in Upper Galilee, in: JBL 100 (1981) 575-600, and David Suter, Fallen Angel, Fallen Priest: The Problem of Family Purity in 1 Enoch 1-16, in: HUCA 50 (1979) 115-35 argue that the marriages being criticized are marriages between priests and foreign women. Eibert J. C. Tigchelaar, The Prophets of Old and the Day of the End: Zechariah, the Book of the Watchers and Apocalyptic (Leiden, New York, Köln 1996) 198-203, suggests the Book of the Watchers had in mind the priests Josephus tells us followed their Samaritan wives to the temple on Gerizim (Jewish Antiquities 11.312). I have recently argued that the marriages in question are not with foreign women, but rather women from non-priestly families: Levi, Phinehas, and the Problem of Intermarriage at the Time of the Maccabean Revolt, in: JSQ 6 (1999) 6-12.

64 See, e.g: The Paradoxical Ascent to God: The Kabbalistic Theosophy of Habad Hasidism, trans. Jeffrey M. Green (SUNY series in Judaica, Albany 1993), and: Hasidic Thought: Mystical Origins and Kabbalistic Foundations (Hebr.) (Sifriyat "Universitah meshuderet", Tel Aviv 1999). 
restricted to the enthronement passage in Hekbalot Rabbati. For the literature of the Second Temple period, as far as I can see, there is no evidence at all. Here, I believe, Elior's knowledge of later Jewish mysticism has led her to see sacred marriage where there is none.

Finally, I would like to consider Elior's treatment of the relationship between the hekhalot literature and earlier merkavah traditions on the one hand and the hekhalot literature and the thought of the rabbis on the other. For Scholem, as we have seen, the tannaim provided a conduit for merkavah mysticism from the apocalypses of the Second Temple period to the hekhalot literature. Without the tannaim, Elior has to offer a different kind of explanation for what she sees as significant continuity between the apocalypses and the hekhalot texts. Elior makes this task particularly difficult because she claims that there is a profound opposition between the worldview of the secessionist priests and the worldview of the rabbis, views she characterizes as standing in a "sharply polar relationship... an antithetical correlation", or as "diametrically opposed" 65 , she even notes fourteen areas in which this opposition can be seen ${ }^{66}$.

The gulf Elior sees is so wide that it is more than a little surprising that after the rabbis had achieved religious dominance the traditions of the secessionist priesthood reemerge in hekhalot literature ${ }^{67}$. Elior's explanation is that with the loss of the temple, many of the issues that once divided the secessionist priests and the ancestors of the rabbis were no longer relevant. Other issues, such as calendar, have been resolved in the rabbis' favor. In this new environment, she implies, it was possible for aspects of the worldview of the secessionist priests that did not threaten the rabbis to gain acceptance. Thus the polemical literature of the secessionist priests was no longer relevant to their post-destruction heirs, while the ancient texts and traditions about the heavenly temple and its cult continued to be meaningful68. This explanation is quite plausible, though it seems to me to conflict with the view that the differences between worldviews were absolute. Nor does Elior consider the implications of the hekhalot texts' use of rabbis as their pseudepigraphic heroes ${ }^{69}$. She discusses these heroes briefly, emphasizing Rabbi Ishmael's identity as high priest and suggesting that the pairing of Rabbi Ishmael and Rabbi Akiva is meant to recall the figures of Aaron and Moses ${ }^{70}$. But she makes no effort to address the significance of rabbinic heroes for her view of the extreme opposition between worldviews.

65 Elior, Three Temples 212.

66 Elior, Three Temples 213-29.

67 Elior does not discuss the dating of the hekhalot texts. While Scholem placed them in the rabbinic period, scholars writing more recently, such as Schäfer, Hidden and Manifest God, and Swartz, Scholastic Magic, suggest a date in the period after the completion of the Babylonian Talmud.

68 Elior, Three Temples 233, 263-64.

69 On the significance of rabbinic heroes for the context of the hekhalot texts: Scbäfer, Hidden and Manifest God 159-60, with criticism of the theory of Halperin, Faces of the Chariot, and Schäfer, Aim and Purpose 293.

70 Elior, Three Temples 240-43. 
Elior admits that we know little about the historical circumstances that account for the transmission of traditions of the Second Temple period to the authors of the hekhalot texts:

"We cannot pinpoint any historical contact between the various priestly circles who committed chapters of Merkavah tradition to writing, both because we have no idea what happened to the Qumran priests and because of the mists that shroud the circumstances and locations in which the authors of Heikhalot literature wrote. In addition we have no independent documentation of the historical identities and real existence of those authors. Nevertheless, there is no denying their common spiritual horizon and their distinct spiritual identity, the continuity of their conceptual tradition, their shared linguistic propensities and recurrent patterns of reference..." 71 .

Despite her observation that the contemplation of the merkavah is unknown in the earlier literature ${ }^{72}$, Elior insists on a remarkable continuity between the literature of the secessionist priesthood and the hekhalot texts. As indications of the continuity she invokes both the figure of Enoch and the prominence of the number 365 in the hekhalot literature:

"The creators of the myth of angelic priests and their successors in Heikhalot and Merkavah literature, whether defiantly, longingly, or hopefully, preserved the memory of the seventh priestly, angelic patriarch, Enoch-Metatron, the supertemporal witness to the solar calendar (who lived 365 years!). They also preserved the memory of the number of days in the solar year in relation to the cosmic pattern of the Merkavah world with its seven heikhalot: 'The Holy One, blessed be he, placed his hand upon me and blessed me with three hundred and sixty-five blessings....".73

But do the elements of hekhalot literature to which Elior points in this passage show what she claims? It is simply not true that Enoch plays a central role in the hekhalot literature. Elior implies that Metatron, the heavenly vice-regent who figures prominently in many passages in hekhalot literature, is always to be identified with Enoch. Yet of all the hekhalot works, only Sefer Hekhalot (3 Enoch) makes this identification ${ }^{74}$. Further, Sefer Hekbalot stands apart from the rest of hekhalot literature in a number of ways ${ }^{75}$. It is probably the most highly redacted of the hekhalot texts, and it appears to be engaged in bringing hekhalot traditions closer to rabbinic thought, as in its incorporation of traditions from the Talmud about Aher's misunderstanding of Metatron. Most important for the question at hand, it stands alone among the hekhalot texts in devoting attention to a hero of apocalyptic literature; as Annette Reed has recently shown, it is dependent not

71 Elior, Three Temples 233.

72 Elior, Three Temples 241.

73 Elior, Three Temples 263.

74 I must confess that I have not been able to locate the text Elior refers to as Shivbei metatron (21, 35n. 23) or Shivbei hanokb-metatron (237).

75 See, e.g.: Schäfer, Hidden and Manifest God 123-38, 147-48. 
just on traditions about Enoch, but, at one point, on an excerpt from the Book of the Watchers ${ }^{76}$.

As for the traces of the solar calendar Elior detects in the hekhalot literature, it is truly astonishing that she takes the number 365 as a reference to the calendar of the secessionist priests. Indeed one could argue that the passage Elior quotes above from Sefer Hekhalot represents a rejection of the 364-day calendar, a rejection that must be made explicit in a work that embraces Enoch, the ancient hero of that calendar. The number 365, the number of days in an actual solar year, is in fact of some importance for the rabbinic calendar, which is not a fully lunar calendar like that of Islam, but rather a lunar calendar brought into harmony with the solar year over a nineteen-year cycle. It is also the number of years of life attributed to Enoch in Gen 5:23. In other words, the number 365 functions in Sefer Hekhalot much as the incorporation of traditions from the Talmud critical of Metatron functions, to bring the text into greater harmony with the thought of the rabbis.

Elior's overstated claims for continuity between the literature of the Second Temple period and the hekhalot texts are another instance of the central problem of The Three Temples, the harmonization of sources she views as reflecting a common ideology. I have already suggested that Elior's work on later Jewish mysticism led her to see a myth of sacred marriage where there was none. It seems to me that her affinity for harmonization may also reflect a way of looking at texts more appropriate to later Jewish mysticism, where, for example, interpreters of the Zohar, despite the differences among them, were consciously attempting to explicate and develop the teachings of a common text. Certainly it would be wrong to attempt to harmonize the distinctive approaches of different kabbalists to the Zohar, but it is nonetheless meaningful to speak of Zoharic kabbalah because all interpreters share an allegiance to a particular text. As we have seen, the situation is quite different for the ancient texts Elior considers in The Three Temples. Thus, despite its powerful rhetoric and some interesting observations about central texts, the picture The Three Temples proposes of early Jewish mysticism is simply untenable.

76 Annette Yoshiko Reed, From Asael and Šemihazah to Uzzah, Azzah, and Azael: 3 Enoch 5 (SS 7-8) and Jewish Reception-History of 1 Enoch, in: JSQ 8 (2001) 105-36. 